\title{
Religiosity, Ethical Judgments and Malaysian Muslim Students
}

\author{
Rusnah Muhamad \\ University of Malaya, Malaysia
}

\begin{abstract}
Culture is often cited as one of the powerful determinants in shaping the personality and behaviour of individuals. Religion, being an important element of culture, is seen as playing an important role in determining how people behave in certain situations. Various authors have suggested religion as an important dimension in Malaysian ethical behaviour studies especially for the Malays. Yet this construct is generally ignored or incorporated into other constructs. This study investigates the influence of religious education on the perceptions of unethical business practices among final year students in one of the local universities in Malaysia. In particular, this study examines the impact of education stream on the level of religious commitment among Malay Muslim students and how these two variables influence their ethical judgment. It was found that the level of religiosity is negative and significantly related to the level of tolerant towards unethical business practices. The findings also establish that more students from the religious education stream are found to be more religious and consequently, are less tolerance towards unethical business practices.
\end{abstract}

\section{Keywords}

Religiosity; Islamic business ethics; unethical business practices; Malay Muslims.

\section{Introduction}

The relationship between the cultural environment and ethical perceptions has been widely explored (see for example Hunt and Vitel, 1986; Choi, 2001; Srnka, 2004). Culture, through its components, elements and dimensions, is seen to dictate the organizational structures, the micro-organizational behavior, and the cognitive functioning of individuals, in such a way as to ultimately affect the judgment or decision made (Choi, 2001).

This study investigates the influence of the education stream on the level of religious commitment and ethical awareness of the final year students in one of the local universities in Malaysia. In particular, the study examines the relationships between the different streams of education of the students (that is, religious stream versus secular stream) and their level of religious commitment as measured by the Muslim Attitudes towards Religiosity Scale (MARS) (a scale adapted from Wilde and Joseph (1997) and Khashan and Kreidie (2001). Further, the study examines the relationship between the religiosity

Copyright (C) 2009 Victoria University. This document has been published as part of the Journal of Business Systems, Governance and Ethics in both online and print formats. Educational and non-profit institutions are granted a nonexclusive licence to utilise this document in whole or in part for personal or classroom use without fee, provided that correct attribution and citation are made and this copyright statement is reproduced. Any other usage is prohibited without the express permission of the score obtained by these students and their ethical awareness of various businesses conduct. This study highlights the impact of the Islamic religion on the perception of Malays as represented by Malay Muslim students and further reinforces the findings from previous research on business ethical judgments in Malaysia (see for example, Goodwin and Goodwin, 1999; Rashid and Ho, 2003). 
The first section discusses the impact of culture, religion, religiosity and Islamic ethical philosophy. It further reviews previous attempts drawn from the literature to measure religiosity. The second section describes the research framework, followed by a discussion on the research design, data collection and analysis method and the results of the study. The conclusion and recommendations for future research are presented in the final section.

\section{Review of the Literature}

\section{Culture, Religion and Religiosity}

Hofstede (1980) defines culture as the norms, values and beliefs of a particular group or community in a particular area or geographic location, that are shared by its members. More importantly, values are viewed as the deepest level of culture and the most difficult to change, and in turn would affect social systems and institutions in a particular country. According to Blamey and Braithwaite (1997), value is an enduring belief that a specific mode of conduct or end-state of existence is personally or socially preferable to an opposite or converse mode or end-state of existence. Thus, values are the core set of beliefs and principles deemed to be desirable (by groups) of individuals (Andrews, 1987; Mason, 1992). Moreover, values are considered to be general beliefs that define right or wrong (Rashid and Ho, 2003). Arguably, therefore, values could affect how individuals perceive the form of behavior considered appropriate and effective in any given situation.

According to Renzetti and Curran (1998) it was Durkheim (1954) who first provided the sociological definition of religion. Durkheim defines religion as a social institution composed of a unified system of beliefs and practices about sacred things. Renzetti and Curran (1998) explain that the word sacred referred by Durkheim means things regarded by a community of believers as extraordinary and aweinspiring. Renzetti and Curran (1998) noted that according to Durkheim religion serves four major social functions namely social solidarity, social control, providing meaning and purpose to life and providing psychological or emotional support. Therefore, religious beliefs and rituals, then, reinforce group identity, offer solace in times of crisis, and promote morality (Durkheim (1954), as cited by Renzetti and Curran (1998)).

Religion has been identified as one of the critical elements in the cultural environment (Hunt and Vitel, 1986; Sood and Nasu, 1995) since religion affects the way in which people behave (Sadler, 1970), and it is perceived that it may affect an individual's perception. Religion, it is claimed (Sood and Nasu, 1995), would affect individual behavior directly through the rules and taboos it inspires (Harrell, 1986) and indirectly through classification of all phenomena, development of a code of conduct, and establishment of priorities among these codes (Sood and Nasu 1995). More specifically, one (the others are Tawheed and Shariah) of the basic elements of the Islamic religion is Akhlaq (moral and values) providing a framework that shapes the moral and ethical behavior of Muslims in the conduct of all aspects of their life (Ismail, 1990 and Saeed et al., 2001). In addition, it is claimed that the Holy Quran provides a stable and flawless set of values in guiding Muslims' behaviour (Abdullah and Siddique, 1986).

\section{Measures of Religiosity}

Sociologists use the term religiosity to describe an individual's or group's intensity of commitment to a religious belief system (Renzetti and Curran, 1998). According to Scutte and Hosch (1996) religiosity is a difficult construct to measure since there are several definitions of religiosity.

Caird (1987) proposes three different measures of religiosity: cognitive (focus on religious attitudes or beliefs), behavioral (evaluate church attendance or private prayer), and experiential (query as to spiritual experiences). Mookherjee (1993) defines religiosity in terms of public or participatory (based on church membership and the frequency of church attendance) and private or devotional religious behavior (based on the frequency of prayer, bible reading, and a cumulative score of devotional 
intensity). Renzetti and Curran (1998) propose five different dimensions of religiosity: ritualistic religiosity which considers church and synagogue attendance, experiential religiosity which measures how strongly a person feels attached to their religion, ideological religiosity which assesses how committed a person is to religious doctrine or teachings, consequential religiosity which looks at the extent to which religion affects the way a person conducts his or her daily life and intellectual religiosity which focuses on a person's knowledgeability of the history and teachings of a religion. Therefore, it may be concluded from the above discussion that religiosity is a complex social phenomenon that requires multidimensional measurement.

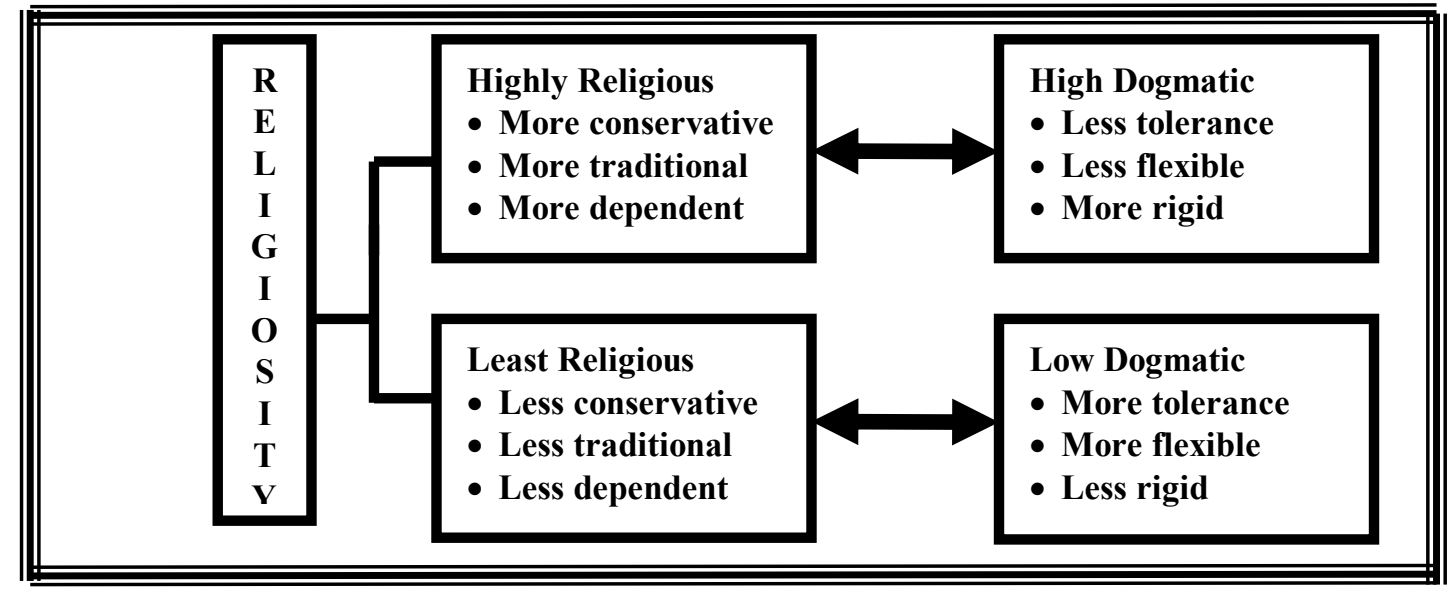

Figure 1: Religiosity and Decision-making (Source: Delener, 1994)

More importantly, it is argued that religiosity or religiousness, as an important value in the individual's cognitive structure, can influence an individual's behaviour (Delener, 1994). According to him the proreligious individuals are likely to be more dogmatic and more conservative than are the non-religious individuals. As such, it is expected that the more religious persons would be more likely to align their behaviour to conform to their religious belief and practices. It is further suggested that those who are strongly committed to religion are both attitudinally and behaviorally capable of making decisions consistent with moral conscience (Pargament et al., 1988; Delener, 1994). A simple paradigm showing the religious variable as a possible factor influencing the decision-making process as hypothesized in the study is illustrated in Figure 1. With regard to this study, it is expected that the respondents who have a higher religiosity score would behave in conformance with the 'desirable' values and behaviours as conceived by the shariah law, and thus, they would be less tolerant towards unethical business activities and practices of the business community.

In examining religiosity in the context of Malay Muslim society, religiosity measures adapted from Wilde and Joseph (1997) and Khashan and Kreidie (2001) that are specific for Muslims are considered appropriate.

\section{The Islamic Ethical Philosophy}

The word 'ethics' originated from the Greek words 'ethos'. Beauchamp and Norman (2003) define ethics as a systematic attempt, through the use of reason to make sense of our individual social and moral experiences, in such a way as to determine the rules that ought to govern human conduct and the values worth pursuing in life. Ethics, according to Stoner et al. (1994) is concerned with "right and wrong". It is an individual's personal beliefs regarding what is right and wrong or good and bad (Davidson and Griffith, 2000). In Islam, ethics is normally used synonymously with morality (Hanafy and Sallam, 2001). It main purpose is to provide a systematic and logical reason or justification for what is right and virtuous and what is wrong and bad. According to Beekun (1997) it is a normative field because it prescribes what one should do or abstain from doing. Ethics, according to Jamal (2003) governs all aspects of a Muslim's life. 
Islamic ethical philosophy has been explored from six main axioms, namely Unity (or Tawheed), Equilibrium, Free Will and Responsibility, Khilafah or Vice-regency and al-adl or Justice (Naqvi, 1981; Chapra, 1992; Alhabsyi and Ghazali,1994). Tawheed or unity is the vertical dimension of Islam (Naqvi, 1981). Bashir (1998) noted that Tawheed entails the unity of life on earth and in the hereafter, and the unconditional surrender by all to the will of God. It integrates the political, economic, social and religious aspects of an individual's life into a homogeneous whole, which is consistent from within the individual himself as well as integrated with the whole Universe.

Khilafah or vice-regency is a special duty of man on this earth (Quran, 2:30; 6:165; 35:39; 38:28; 57:7). Khilafah defines man's status and role and specifies his responsibilities (Bashir, 1998). Khilafah, according to Alhabsyi (1994) implies the universal unity and brotherhood of mankind based on the Islamic faith which claims social equality and dignity of all human beings.

Equilibrium, on the other hand constitutes the horizontal dimension of Islam (Naqvi, 1981). Al-Adl (or justice) according to Alhabsyi (1994) is the rendering of trust where it is due. Trust in this case refers to all aspects of human life including economic, social and legal aspects, both at the individual as well as at the societal levels. In a situation where conflict arises between individual and societal interest, the latter should prevail (Alhabsyi, 1994). Equilibrium is closely related with the concept of justice. The rendering of trust, where it is due, is one of the criteria needed to achieve equilibrium.

Free will according to Naqvi (1981) is the freedom to choose either to become God-like by realizing his theomorphic character or to deny God. However, man's freedom is not absolute, only God is absolutely free. Responsibility is closely related to Free will (Naqvi, 1981) in a sense that it sets limits to what man is free to do by making him responsible for what he does. According to Saeed et al. (2001) there are four categories of responsibility within the Islamic framework. These are responsibility towards God; responsibility towards society; responsibility towards himself; and responsibility towards the environment.

The impact of Islamic religion on different aspects of business is quite substantial since ethics governs all aspects of a Muslim's life (Jamal, 2003). In summary, among the positive values applicable to form a basic framework of Islamic business ethics would be iqtisad (moderation), al-adl (justice), ihsan (kindness par excellence), amanah (honesty), infaq (spending to meet social obligations), sabr (patience) and istislah (public interest). These values should be guiding Muslim businessmen in defining the extent and nature of their activity (Selvaraj and Muhamad, 2004; Rahman, 1994). Lewis (2001) points out values that are negative and thus to be avoided: zulm (tyranny), bukhl (miserliness), hirs (greed), iktikar (hoarding of wealth) and israf (extravagance). Business activities and pursuits within the positive parameters are halal (allowed and praiseworthy) and within the negative parameters are haram (prohibited and blameworthy) and must be moderated. Production and distribution that are regulated by the halal-haram code must adhere to the notion of al-adl (justice). Collectively, these values and concepts, along with the main injunctions of the Quran provide a framework for a just business and commercial system.

Although, it is not easy to locate societies where the Islamic values, moral and ethical principles are truly implemented in every sphere of life, this does not nullify the Islamic model of business ethics (Jamal, 2003). Further, the recent development of Islamic resurgence throughout the Muslim world is witness to a mounting religious commitment among Muslims. According to Esposito (1991) this development has resulted in an increasing emphasis on Islamic law or shariah as a main source of guidance in all aspects of life. Hence, this study is an attempt made to investigate empirically the impact of the Islamic faith on ethical awareness of Muslims in a Muslim majority society as suggested by Jamal (2003).

\section{The Malay Society and the Islamic Religion in Malaysia}

Malaysia is a multiracial country, comprising three major ethnic groups namely the Malays, Chinese and Indians. The Malays account for nearly 60 percent of the total population of 22 million peoples 
(Rashid and Ho, 2003). The Federal Constitution (Article160 [2], states that one of the main criteria in the definition of a "Malay" is that he or she must be a Muslim (Suffian et al., 1978; Mutalib, 1990).

Islam is claimed to be the most important factor in Malay identity as a source of solidarity among members of the community and a form of ethnic differentiation from non-Malays (Gjelsvik, 2001). Accordingly, he argues that Islam provides the social fabric of Malay society in Malaysia. However, from before the spread of the Islamic religion in Malaysia Malay society was already embedded in its 'traditional' norms, practices and systems of social law, or adat (Mutalib, 1990; Kling, 1995; Gjelsvik, 2001). The phenomenon, according to Mutalib (1990) has resulted in a kind of hybrid or variegated Islamic doctrine, consisting of a heavy mixture of both Islamic and un-Islamic practices. The next section discusses briefly the different phases of the business environment and draws on the literature on unethical business practices in Malaysia.

\section{Unethical Business Practices in Malaysia}

Prior to independence from the British in 1957, the Malaysian business sector was largely monopolised by the Chinese and foreign business interests (Selvaraj et al., 2004). The Malays survived as farmers in rural areas and the Indians were mainly confined to the rubber plantations (Rani, 1991). According to Abdullah (1996) the bloody tragedy of May $13^{\text {th }}, 1969$ was a catalyst for Bumiputras (i.e. sons of the soil, referring to the Malays and the indigenous people of Sabah and Sarawak) entrepreneurial development. The tragedy led to the establishment of the New Economic Policy (NEP: 1970-1990) aimed at narrowing the economic gap among the races and restructuring the involvement of different ethnic groups in various economic sectors. The NEP successfully produced established Malay businessmen such as Matshah Safuan of Safuan Holdings, Tan Sri Dato' Azman Hashim of Arab Malaysian Group, Tan Sri Dato' Haji Basir Ismail of Maybank Berhad and the like (Cheong, 1993).

The nature of unethical business practices changes over time. In the 1960s, some investors and businessmen took advantage of poor farmers and fishermen by practicing a monopoly-monopsony system (Aziz, 1964). This is a situation whereby a particular businessman acts as a middleman between suppliers (in this case, farmers and fishermen) buying their products under the concept of monopsony (i.e. when buyers exercise market power (Hyman and Kovacic, 2004) and consumers, reselling these products under the concept of monopoly (i.e. when sellers exercise market power (Hyman and Kovacic, 2004). According to Aziz (1964) such a system basically involves unethical business practices with respect to weighing and measuring. The unethical problems in business become more complex and sophisticated (such as short selling of shares, mismanagement of assets, fraud and insider trading) in the1980s and in some cases have resulted in serious crimes. The murder of Jalil Ibrahim, the chief auditor of Bank Bumiputra Berhad in Hong Kong in 1983 is an example of a crime related to business (Abadi, 1983).

Hussin (2001) observes that Malaysians perceive the present business practices by Malaysian businessmen as being tolerable even though several incidences of wrongdoings are reported in the media. The Muslim businessman is considered to be involved in unethical business practices the moment he is involved in businesses that are not allowable (haram) in Islam such as dealing with liquor, gambling, financial activities involving riba (Hussin, 2003). He observed that many Malaysians are involved in these types of businesses.

\section{The Research Framework}

The framework for this study is developed based on Hunt and Vitel (1986) and Stajkovic and Luthans (1997). As shown in Figure 2, the model indicates that the perceived ethical standards of an individual and the resulting ethical behavioral conduct are grounded in the unique characteristics of a specific culture of a society. Particularly, this study focuses on religion (in this context the Islamic religion) as the main element of culture in shaping personal values and belief of members of a society. Specifically, the study investigates the impact of the education stream on the level of religiosity of the Malay Muslim students and how these two variables influence their ethical awareness. 


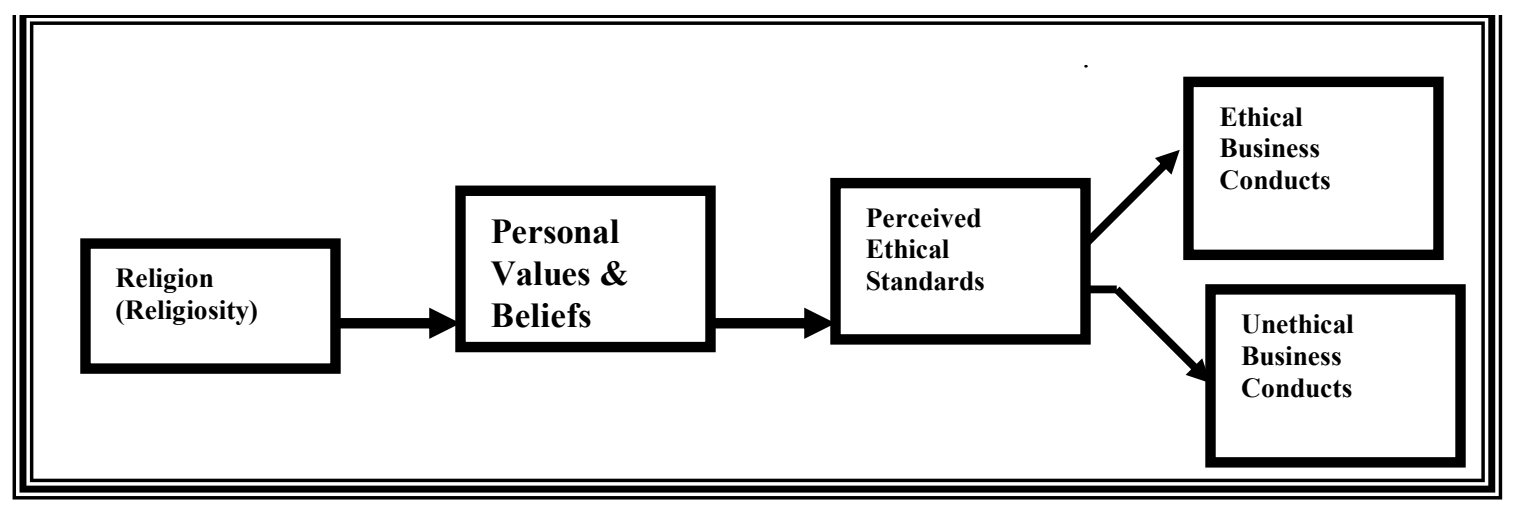

Figure 2: Research Framework (Adapted from Hunt and Vitel, 1986 and Stajkovic and Luthans, 1997)

\section{Hypothesis Development}

Prior research suggests that the degree of religiosity has a possible influence on the ethical awareness of individuals. Works on religiosity have tended to focus almost exclusively on Christianity (Wilde and Joseph, 1997). However, it is difficult to build upon on the findings of previous studies of the relationship between religion and ethical judgments in the Muslim society context, due to lack of research in this area. Nevertheless, from the research framework depicted in Figure 2 it is expected that the respondents who have a higher religious commitment would be less tolerant, than those with low commitment, towards unethical business activities practiced by the business community. The respondents in this study are represented by Malay Muslim students in one of the local public universities in Malaysia. A student group is selected in view of the fact that these students will soon become key members of Muslim society. As noted by Alam (1995) they will become future leaders, managers and administrators. As such, the results may be expected to provide some indication of how the future generation of Malay Muslims might be expected to behave. Hence, the hypothesis examined is:

\section{H1: Malay Muslim students who are more religious are less tolerant towards unethical business activities practiced by the business community as compared to Malay Muslim students who are less religious.}

It was observed that the Chinese stream of education of Malaysian Chinese has influence on the score of Chineseness (Ong, 1993). Thus, in the same line of thought since Chinese education would be able to influence the Chineseness among the Chinese, it's also posited that Islamic religious education would be able to influence the level of religious commitment among the Muslims. Therefore, it is hypothesized that religious education would be able to influence the degree of religiosity of Malay Muslim students as represented by their religiosity score and accordingly would influence their perceptions on unethical business practices. As such, the related hypotheses examined are:

H2: The religiosity score of Malay Muslim students from the religious education stream is higher than that of Malay Muslim students from the secular education stream.

H3: Malay Muslim students from the religious education stream are less tolerant towards unethical business activities practiced by the business community compared to Malay Muslim students from the secular education stream.

\section{Research Design, Data Collection and Method of Analysis}

The religious commitment (or religiosity) examined in this study is from the context of the Islamic religion. The awareness on unethical behavior collated in the survey for this study is mainly related to the basic elements of Islamic business ethics such as involvement in haram (prohibited) businesses, cheating, bribery and profiteering. The main purpose is to investigate the level of tolerance among the Muslim students towards these activities as practiced by the business community. 
The stated hypothesis was tested using an independent samples t-test and simple regression analysis by running the Statistical Package for Social Sciences (SPSS) software. For this purpose, the respondents are categorized into two groups: the more religious group and the less religious group. Chi-square analysis was carried out to examine the relationship between religiosity and unethical business practices scores with selected demographic variables, namely gender and stream of education.

The questionnaire designed for this study is divided into three parts. Section A is related to the personal background of respondents, Section B is related to the moral judgment of Malay Muslims towards unethical business activities practiced by the business community. Finally, Section $\mathrm{C}$ measures the religiosity score (MARS) of the respondents. Questions on unethical business practices (in section B as adopted from Hussin, 2001) were presented in a 7-point Likert scale, 1 being "more ethical" and 7 being "less ethical". As such the higher the score a respondent gets for this section, the more tolerant he/she will be towards unethical business activities practiced by businesses. The religious questions (in Section C) are presented in a 5-point Likert scale (1 being "less religious" and 5 being "more religious") and the behavior question in a semantic differential scale (either in the form of strong believer - strong disbeliever and very religious - very unreligious). The higher score indicates that a respondent has stronger adherence to the Islamic religion.

A total of 429 students from the Faculty of Business and Accountancy and Academy of Islamic Studies University of Malaya took part in the survey. Once gathered, the data were tested for normality and reliability. An examination of the values of skewness and kurtosis indicate that all items are reasonably normally distributed. The Cronbach alpha coefficient for the unethical business practices and religiosity items are 0.9016 and 0.7464 respectively. According to Nunnally (1967) coefficient of 0.6 or 0.5 will suffice. Thus, these levels of reliability are sufficiently high.

\section{Findings}

A total of 429 completed questionnaires were used for this study. Ninety nine per cent of the students are between 23 to 25 years old and $65 \%$ are female. Forty per cent of them were undertaking Islamic studies (considered a religious stream) and the rest are either accounting or business majors (considered a secular stream).

\section{Religiosity and Ethical Awareness}

The religiosity of the respondents was determined by using percentiles (Ong, 1993) whereby the upper and the lower thirds of the distribution are identified as the more religious and less religious. Thus, respondents with scores of lower than 100 (131 respondents or 30.1\%) were labeled as less religious and those with scores of 104 and above (142 respondents or 33.1\%) were categorized as the more religious group. The same procedure was followed for business perception scores. Respondents with scores of lower than 50 (144 respondents or $33.6 \%$ ) were regarded as more ethical while those with scores of 71 and above (147 respondents or $34.3 \%$ ) were deemed to be less ethical.

Table 1: T-test Result

\begin{tabular}{|l|l|l|l|l|}
\hline & $\mathrm{t}$ & $\mathrm{p}$ & Mean & Eta square \\
\hline $\begin{array}{l}\text { Business } \\
\text { Practices/Religiosity }\end{array}$ & 6.890 & 0.000 & $\begin{array}{l}\text { More religious=54.0; } \\
\text { Less religious=68.54 }\end{array}$ & 0.15 \\
\hline $\begin{array}{l}\text { Religiosity/Education } \\
\text { stream }\end{array}$ & 7.525 & 0.000 & $\begin{array}{l}\text { Religious Stream=103.10; } \\
\text { Secular Stream=98.6 }\end{array}$ & 0.12 \\
\hline $\begin{array}{l}\text { Business } \\
\text { Practices/Education stream }\end{array}$ & 4.969 & 0.000 & $\begin{array}{l}\text { Religious Stream=56.49; } \\
\text { Secular Stream=66.05 }\end{array}$ & 0.05 \\
\hline
\end{tabular}


The results from independent samples t-test is shown in Table 1. The result reveals that the three stated hypotheses have been supported whereby the $\mathrm{p}$ values were found to be significant. As for $\mathrm{Hl}$, Malay Muslim students who have a higher religiosity score (or more religious) are less tolerant towards unethical business activities. The lower mean score $(\mathrm{M}=54.0)$ for the more religious respondents indicates that they are less tolerant towards unethical activities practiced by businesses. The mean score $(\mathrm{M}=68.54)$ for the less religious respondents are higher, indicating that they are deemed to be less ethical. Therefore we accept $H 1$ - the more religious Malay Muslim students are less tolerant towards unethical business activities practiced by the business community.

It was posited in $\mathrm{H} 2$ that the religiosity score of the Malay Muslim students from the religious education stream is higher than that of Malay Muslim students from the secular education stream As presented in Table 1, the mean score $(\mathrm{M}=103.10)$ of religiosity measurement for the religious stream respondents is higher than that from the secular stream $(\mathrm{M}=98.60)$ indicating that they have higher religious commitment and are deemed to be more religious.

Consequently, in $\mathrm{H3}$ it is indicated that Malay Muslim students from the religious education stream are less tolerant towards unethical business activities practiced by the business community compared to respondents who are from the secular education stream. Table 1 reveals that the lower mean score $(\mathrm{M}=56.49)$ of unethical business practices for the religious education stream students shows that this group are less tolerant towards unethical business activities practised by the business community.

Eta squared ( $\mathrm{y}$ ) was calculated to determine the magnitude of the differences between the groups examined (Pallant, 2001). As shown in the table, the differences are considered large for the ethical awareness vs different religiosity groups $(\mathrm{y}=0.15)$; moderate for religiosity score vs different education streams $(\mathrm{y}=0.12)$; and small for the ethical awareness vs different education streams $(\mathrm{y}=0.05)$.

Table 2: Regression Model Results (ANOVA Table)

\begin{tabular}{|l|l|l|l|l|l|}
\hline Model & SS & df & MS & F & Sig. \\
\hline Regression & 15165.745 & 1 & 15165.745 & 45.675 & .000 \\
\hline Residual & 141778.41 & 427 & 332.034 & & \\
\hline Total & 156944.16 & 428 & & & \\
\hline
\end{tabular}

Table 3: Regression Model Results (Coefficients)

\begin{tabular}{|c|c|c|c|c|c|}
\hline \multirow[b]{2}{*}{ Model } & \multicolumn{2}{|c|}{ Unstandardized Coefficients } & Standardized Coefficients & \multirow[b]{2}{*}{$\mathrm{t}$} & \multirow[b]{2}{*}{ Sig } \\
\hline & B & Stad. Error & Beta & & \\
\hline \multirow{2}{*}{$\begin{array}{l}\text { Religiosity } \\
\text { (const) } R^{2}= \\
.097\end{array}$} & 148.473 & 12.796 & \multirow[b]{2}{*}{-.311} & 11.603 & .000 \\
\hline & -.859 & .127 & & & .000 \\
\hline
\end{tabular}

The regression results are depicted in Tables 2 and 3. The regression coefficient for religious commitment (-.859), indicates that students who are more religious evaluated the unethical business activities as more unethical than did those with lower levels of religiosity score. In other words, an inverse relationship exists between religiosity score and perceived unethical business practices, or ethical awareness. 
Table 4: Religiosity and Business Practices Score within Gender and Education Stream.

\begin{tabular}{|c|c|c|c|c|}
\hline & \multicolumn{2}{|l|}{ Religiosity } & \multicolumn{2}{|c|}{ Business Practices } \\
\hline & $\begin{array}{l}\text { Less religious } \\
(\mathrm{n}=131)\end{array}$ & $\begin{array}{l}\text { More religious } \\
(\mathrm{n}=142)\end{array}$ & Ethical $(n=144)$ & $\begin{array}{l}\text { Unethical } \\
(\mathrm{n}=147)\end{array}$ \\
\hline \multicolumn{5}{|l|}{ Gender } \\
\hline Male & $36(34.6 \%)$ & $68(65.4 \%)$ & $83(72.2 \%)$ & $32(27.8 \%)$ \\
\hline Total & \multicolumn{2}{|l|}{104} & \multicolumn{2}{|l|}{115} \\
\hline Female & $95(56.2 \%)$ & $74(43.8 \%)$ & $61(34.7 \%)$ & $115(65.3 \%)$ \\
\hline Total & \multicolumn{2}{|l|}{169} & \multicolumn{2}{|l|}{176} \\
\hline $\begin{array}{l}\chi^{2} \text { highly significant } \\
\text { at }>.001\end{array}$ & \multicolumn{2}{|c|}{$\begin{array}{l}\text { Cramer's V value }=0.188 ; p= \\
0.000,(p<0.001)\end{array}$} & \multicolumn{2}{|c|}{$\begin{array}{l}\text { Cramer's V value }=0.336 ; p= \\
0.000,(p<0.001)\end{array}$} \\
\hline \multicolumn{5}{|l|}{ Education Stream } \\
\hline Secular & $109(66.5 \%)$ & $55(33.5 \%)$ & $46(29.3 \%)$ & $111(70.7 \%)$ \\
\hline Total & \multicolumn{2}{|l|}{164} & \multicolumn{2}{|l|}{157} \\
\hline Religious & $22(20.2 \%)$ & $87(79.8 \%)$ & $98(73.1 \%)$ & $36(26.9 \%)$ \\
\hline Total & \multicolumn{2}{|l|}{109} & \multicolumn{2}{|l|}{134} \\
\hline $\begin{array}{lr}\mathrm{X}^{2} & \text { highly } \\
\text { significant at }>.001\end{array}$ & \multicolumn{2}{|c|}{$\begin{array}{l}\text { Cramer's V value }=0.361 ; p= \\
0.000(p<0.01)\end{array}$} & \multicolumn{2}{|c|}{$\begin{array}{l}\text { Cramer's V value }=0.403 ; \mathrm{p}= \\
0.000(\mathrm{p}<0.01)\end{array}$} \\
\hline
\end{tabular}

The result of cross-tabulation between gender and education stream with religiosity and unethical business practices scores show that there is a relationship between these variables. As presented in Table 4, 56.2 \% of the female Malay Muslim students are found to be less religious, while $65.4 \%$ of the male Malay Muslim students belong to the more religious group. In terms of their ethical awareness more male Malay Muslim students $(72.2 \%)$ view the unethical activities as more unethical, and therefore are deemed to be more ethical, as compared to the female Malay Muslim students $(34.7 \%)$. It was found that $65.3 \%$ of the female Malay Muslim students fall in the category of less ethical in terms of their perception on unethical business practices.

The result of cross-tabulation between the education stream with religiosity and unethical business practices scores reveal that $66.5 \%$ of Malay Muslim students from the secular education stream are less religious and $70.7 \%$ of them are found to be more tolerant of unethical business practices and thus, are less ethical. On the other hand, $79.8 \%$ of Malay Muslim students from the religious education stream are found to be more religious and $73.1 \%$ of them are considered as more ethical.

Therefore, chi-square analysis was carried out to investigate the relationship between these two scores and the two demographic variables. Both gender and education stream were significantly related to religiosity score $(\mathrm{p}<0.001)$ and unethical business practices scores $(\mathrm{p}<0.001)$. In addition, the Cramer's $\mathrm{V}$ values were used to determine the strength of association between these variables (Field, 2000; Foster, 2001). This measure lies between 0 and 1 and is considered significantly different from 0 if the observed value of $\chi^{2}$ is significant (Mendenhal et al., 1993). As noted in Table 4 the relationship between these variables can be considered as slightly weak since the Cramer's V values obtained for these variables were quite low. However, these relationships were significant because the observed $\chi^{2}$ $(p<0.000)$ were significant. 


\section{Conclusion}

The study suggests that the degree of religiosity has a significant influence on the ethical awareness of Malay Muslims in Malaysia. This conclusion is qualified by the finding, however, religiosity only contributes $9.7 \%$ towards the respondents' perceptions. Malays uphold strongly the value of selfrespect or preserving face as one of the important values (Abdullah, 1996; McLaren and Rashid, 2002). As such they would not willingly disclose information regarding unacceptable religious behavior. Thus, they may not want to admit that they are not strong believers and do not perform the obligatory duty for Muslims such as the five daily prayers, fasting in the month of Ramadan and zakat. Another possible explanation is that Malay Muslims are deeply embedded in the various systems inherited from the British colonial period that are incompatible with Islamic values (Mutalib, 1990). As such, some practices that are considered against Islamic values (for example transactions involving interest) have been accepted as norms in the business society. The findings reported in this study are consistent with Hassan's (1986) observation of Malaysian Muslims. According to him, Islam does not influence all aspects of the behavior of Malay Muslims in Malaysia.

According to Alhabsyi and Ghazali (1994) the majority of Malaysian Muslims would abide by most of the dictates of their religion in so far as their consumption goes. According to him, they are very particular as far as consuming the lawful items are concerned. However, they are not very particular about whether their incomes are completely lawfully earned. For example, the recent issue of two factories in Selayang producing sausages using pig intestines has witnessed mounting dissatisfaction and retaliation from Muslims (Utusan Malaysia, 2005).

The study also reveals that the education stream (i.e. secular versus religious) is able to influence the religious commitment among Malay Muslims and consequently influence their perception towards unethical business activities practiced by businesses in society. Thus, the intensity of religious education does play a role in inculcating good values and religious commitment among the Malay Muslims. Perhaps policy makers should consider an integrated education system to integrate both worldly and spiritual values in youngsters for the betterment of the society.

Future research may be extended to investigate the influence of other factors on ethical awareness such as age, professions and income. The influence of these factors could not be examined in the present study since the respondents were among university undergraduate students.

\section{References}

Abadi, A 1983, Skandal BMF pedih dan memalukan, Gatra Jaya, Kuala Lumpur.

Abdullah, A. 1996, Going global - cultural dimensions in Malaysian management

(Malaysian Institute of Management, Kuala Lumpur).

Abdullah, T \& Siddique, S 1986, Islam and society in Southeast Asia, Institute of Southern Asian Studies, Singapore.

Andrews, KR 1987 The Concept of Corporate Strategy, Irwin, New York.

Alam, KF 1995, 'Attitudes towards business ethics of business students in Malaysia', Journal of Business Ethics, vol. 14, pp. 309-313.

Alhabshi, S O \& Ghazali, A (eds) 1994, Islamic values and management, Institute of Islamic Understandings Malaysia, Kuala Lumpur.

AlHabshi, S. O. (1994). 'Islamic Values: Its Universal Nature and Applicability', In: AlHabshi, S. O. and Ghazali, A. (eds) Islamic Values and Management, Kuala Lumpur: Institute of Islamic Understandings Malaysia, pp. 7-21.

Aziz, U 1964, 'Poverty and rural development in Malaysia', Kajian Ekonomi Malaysia, vol 1, no. 1.

Bashir, AH 1998, 'Ethical norms and enforcement mechanism in profit-sharing agreement', MidAtlantic Journal of Business, vol. 34, pp. 255-271.

Beauchamp, LT \& Norman, EB 2003, Ethical theory and business, $7^{\text {th }}$ Edition, New Jersey, PrenticeHall. 
Beekun, R. I. (1997). Islamic Business Ethics, Virginia; International Institute of Islamic Thought.

Blamey, R \& Braithwaite, V 1997, 'A social value segmentation of the potential ecotourism market', Journal of Sustainable Tourism, vol. 5, no. 1, pp. 29-45.

Caird, D 1987, 'Religiosity and personality: are mystic introverted, neurotic, or psychotic? British Journal of Social Psychology, vol. 26, pp. 345-346.

Chapra, MU 1992, Islam and the economic challenge, The Islamic Foundation, Leceister, UK.

Cheong, S 1993, Bumiputera controlled companies in the KLSE, Corporate Research Service Sdn Bhd, Petaling Jaya.

Choi, JS 2001, 'Financial crisis and accounting reform: a cultural perspective,' proceeding of the Third Asian Pacific Interdisciplinary Research in Accounting Conference, Adelaide, Australia.

Davidson, P \& Griffith, RW 2000, Management in a global context, John Wiley and Sons, Brisbane, QLD.

Delener, N 1994, 'Religious contrasts in consumer decision behavior patterns: their dimensions and marketing implications', European Journal of Marketing, vol. 28, no. 5, pp. 36-53.

Durkheim, E 1954 The elementary forms of religious life, The Free Press, London.

Esposito, JL 1991 Islam: The Straight Path, Oxford University Press, New York.

Field, A 2000, Discovering statistic using SPSS for Windows: advanced techniques for the beginner, SAGE Publication, London.

Foster, JJ 2001, Data analysis using SPSS for Windows version 8 to 10: a beginner guide, SAGE Publication, London.

Gjelsvik, J T 2001, Influence of Islamic culture on scandinavian management in Malaysia - a gance at multinational management and Islamic values, Master Thesis, Institute of Classical Philology, Russian and the History of Religions, The University of Bergen, Norway.

Goodwin, J \& Goodwin, D 1999, 'Ethical judgments across cultures: a comparison between business students from Malaysia and New Zealand', Journal of Business Ethics, vol. 18, pp. 267-281.

Hanafy, AA \& Sallam, H 2001 'Business Ethics: An Islamic Perspective'. In Ahmad, K and Sadeq, AM (eds). Ethics in Business and Management: Islamic and Mainstream Approaches. Asean Academic Press, London, pp. 169-187.

Harrell, GD 1986, Consumer behavior, Harcourt Brace, Javanovich.

Hassan, MH 1986 'Dimension of Islamic Education'. In Abdullah, T \& Siddique, S (eds). Islam and Society in Southeast Asia, Institute of Southern Asian Studies, Singapore.

Hofstede, G 1980, Culture consequences: international differences in work related values, Sage Publications.

Hunt, SD \& Vitel S 1986, 'A general theory of marketing ethics'. Journal of Macromarketing, vol. 8, pp. 5-16.

Hussin, WSW 2001, Nilai dan etika Islam dalam perniagaan - amalan \& tanggapan masyarakat Malaysia, Ph.D Disertation, University of Malaya, Kuala Lumpur.

(2003), Etika dan amalan perniagaan, Utusan Publications, Kuala Lumpur.

Hyman, DA \& Kovacic, WE 2004 'Monopoly, monopsony, and market definition: an antitrust perspective on market concentration among health insurers', Health Affairs, vol. 23, no 6. pp. 25-28.

Ismail, AH 1990, The teaching of Islamic economics: the practitioner's point of view, Paper presented at the workshop on the Teaching of Islamic Economics, International Islamic University, Malaysia.

Jamal, US 2003, 'Understanding the framework of business in Islam in an era of globalization: a review', Business Ethics: A European Review, vol. 12, no. 1, pp. 23-30.

Khashan, H \& Kreidie, L 2001, 'The social and economic correlates of Islamic religiosity', World Affairs, vol. 164, No. 2. Fall.

Kling, Z 1995 'The Malay Family: Beliefs and Realities', Journal of Comparative Family Studies, Vol. XXVI, No. 1, Spring, pp. 43-66.

Lewis, MK 2001, 'Islam and accounting', Accounting Forum, vol. 25, no. 2, pp.103-127.

Mason, DE 1992, 'Values for ethical choices: rate yourself', Nonprofit World, vol. 10, no. 3, pp. 2325.

McLaren, MC \& Rashid, MZA 2002 Issues and Cases in Cross-Cultural Management: An Asian Perspective, Prentice-Hall, Kuala Lumpur. 
Mookherjee, H N 1993, 'Effects of religiosity and selected variables on the perception of well-being', The Journal of Social Psychology, vol. 134, no. 3, pp. 403-405.

Mutalib, H 1990, Islam and ethnicity in Malay politics, Oxford University Press, Kuala Lumpur.

Naqvi, SNH 1981, Ethics and economics: an Islamic synthesis, The Islamic Foundation, UK.

Nunnally, JCJr 1967, Psychometric theory, McGraw-Hill, New York, NY.

Ong,FS 1993, 'Chinese ethnicity: it relationship to some selected aspects of consumer behavior', Malaysian Management Review, vol. 28, no. 2, pp. 29-43.

Pallant , J 2001, A step by step guide to data analysis using SPSS, Open University Press, Buckingham.

Pargament, KI, Kennell, J, Hathaway, W, Grevengoed, N, Newman, J Jones, W 1988, 'Religion and the problem-solving process: three styles of coping', Journal for the Scientific Study of Religion, vol. 27, pp. 90-104.

Rahman, YA 1994, Interest free Islamic banking, Al-Hilal Publishing, Kuala Lumpur.

Rani, HO 1991 'Penyusunan Semula Masyarakat: Persaingan, Keadilan dan Perpaduan. In Muhamed, K \& Awang, H (eds), Dasar Ekonomi Dan Masa Depannya, Persatuan Sains Sosial Malaysia, Kuala Lumpur.

Rashid, AMZ \& Ho, JA 2003, 'Perceptions of business ethics in a multicultural community: the case of Malaysia', Journal of Business Ethics, vol. 43, pp. 75-87.

Renzetti, CM \& Curran, DJ 1998, Living Sociology, Allyn \& Bacon, United State.

Saeed, M, Ahmed, ZU \& Mukhtar, SM 2001, 'International marketing ethics from an Islamic perspective: a value-maximization approach', Journal of Business Ethics, vol. 32, no. 2, pp. 127 142.

Sadler, W 1970, Personality and religion: the role of religion in personality development, SCM Press Ltd, London.

Scutte, JW \& Hosch, HM 1996, 'Optimism, religiosity and neuroticism: a cross-cultural study', Personality and Individual Differences, vol. 20, issue 2, pp 239-244.

Selvaraj, SD \& Muhamad, R 2004 'Islamic Accounting', In Selvaraj, SD, Hooper, K \& Davey, H (eds) 2004, Accounting theory and practice: a Malaysian perspective, Pearson Education Malaysia, Kuala Lumpur, pp. 205-254.

, Hooper, K \& Davey, H (eds) 2004, Accounting theory and practice: a Malaysian perspective, Pearson Education Malaysia, Kuala Lumpur.

Sood, J \& Nasu, Y 1995, 'Religiosity and nationality an exploratory study of their effect on consumer behavior in Japan and the United States', Journal of Business Research. Vol. 34, pp. 1-9.

Srnka, KJ 2004, 'Culture's role in marketers' ethical decision making: an integrated theoretical framework', Academy of Marketing Science Review, no. 01, pp 1-26.

Stajkovic, AD \& Luthans, F 1997, 'Business ethics across cultures: a social cognitive model', Journal of World Business, vol. 32, no. 1, pp 17-34.

Stoner, JAF, Yetton, PW, Craig, JF \& Johnston, KD 1994, Management $\left(2^{\text {nd }}\right.$ Ed.), Prentice Hall Australia, Sudney.

Suffian, M, Lee, HP, \& Trindade, FA (eds) 1978, The constitution of Malaysia, its development: 1957-1977, Oxford University Press, Kuala Lumpur.

Utusan Malaysia 2005 'Sosej babi: Imej Malaysia boleh terjejas'.

Wilde, A \& Joseph, S 1997, 'Religiosity and personality in a Moslem context', Personality and Individual Differences, vol. 23, Issue 5, pp 899-900. 